Економічні науки: збірник наукових праць Луцького національного технічного університету. Серія "Регіональна економіка". Випуск 18 (71). Редкол.: відп. ред. д.е.н., професор Л.Л. Ковальська. Луиьк: ІВВ Луиького НТУ, 2021. 278 с.

УДК 330.3

Оксенюк К.І., к.е.н., доцент

Нікітін Т.O.

Луцький національний технічний університет

\title{
ПІДВИЩЕННЯ ЕФЕКТИВНОСТІ ЛОГІСТИЧНИХ ПРОЦЕСІВ ШЛЯХОМ ВИКОРИСТАННЯ ІНФОРМАЦІЙНИХ ТЕХНОЛОГІЙ
}

У статті досліджено ключові аспекти підвищення ефективності логістичних процесів шляхом використання інформаційних технологій. Доведено, що інформаційні технології $\epsilon$ інструментом управління, який служить для координації і контролю логістичних процесів. Проаналізовано інформаційні технології: Big Data, аналітичні платформи ланцюгів постачань, інтернет речей, штучний інтелект, машинне навчання, блокчейн.

Ключові слова: логістичний процес, інформаційні технології, Big Data, інтернет речей, штучний інтелект, машинне навчання, блокчейн.

Oksenyuk K., Nikitin T.

\section{IMPROVING THE EFFICIENCY OF LOGISTICS PROCESSES THROUGH THE USE OF INFORMATION TECHNOLOGIES}

The article examines the key aspects of improving the efficiency of logistics processes using Information Technologies. It is proved that information technologies are a management tool that serves to coordinate and control business in general and logistics processes in particular. Information technologies contribute to the rational management of all types of enterprise resources; improve the use of warehouse capacities, automated cargo selection and production inventory management.

The international logistics performance indicator (LPI) is analysed. LPI takes into account the expert assessment of customs functioning, logistics infrastructure, international deliveries, tracking of deliveries, timely deliveries and logistics competencies. The logistics index fluctuates with negative dynamics, which is due to two factors: inefficient work of customs authorities, deterioration of infrastructure. Timeliness and tracking indicators are above average, which has a positive effect on the logistics efficiency index. Indicators of international shipments and logistics competencies are at an average level. According to the logistics efficiency index, Ukraine ranks 69th in the world ranking.

To improve the efficiency of logistics processes, information technologies were analysed: Big Data, supply chain analytical platforms, Internet of Things, artificial intelligence, machine learning, and blockchain. The above technologies are based on collecting and analysing large amounts of information to find optimal 
Економічні науки: збірник наукових праць Луцького національного технічного університету. Серія "Регіональна економіка". Випуск 18 (71). Редкол.: відп. ред. д.е.н., професор Л.Л. Ковальська. Луцьк: ІВВ Луцького НТУ, 2021. 278 с.

supply chains and improve the efficiency of logistics processes. The features of using information technologies in the implementation of internal logistics processes at enterprises are determined.

The problems of developing logistics processes are the high level of corruption, imperfect legislative framework and inefficient work of Customs and border authorities, low logistics infrastructure (2.38 on the LPI and 105th place in the world) and low rates of innovative development.

The introduction of information technologies in logistics processes will improve interaction between all participants in the logistics process, contribute to increasing productivity and strategic planning, and ensure profitability growth.

Key words: logistics process, efficiency, information technology, Big Data, internet of things, artificial intelligence, machine learning, blockchain.

\section{Оксенюк Е.И., Никитин Т.О. \\ ПОВЫШЕНИЕ ЭФФЕКТИВНОСТИ ЛОГИСТИЧЕСКИХ ПРОЦЕССОВ ПУТЕМ ИСПОЛЬЗОВАНИЯ ИНФОРМАЦИОННЫХ ТЕХНОЛОГИЙ}

В статье исследованы ключевые аспекты повышения эффективности логистических процессов путем использования информационных технологий. Доказано, что информационные технологии являются инструментом управления, который служит для координации и контроля логистических процессов. Проанализированы информационные технологии: Big Data, аналитические платформы цепей снабжений, интернет вещей, искусственный интеллект, машинная учеба, блокчейн.

Ключевые слова: логистический процесс, информационные технологи, Big Data, интернет вещей, искусственный интеллект, машинная учеба, блокчейн.

Постановка проблеми у загальному вигляді і її зв'язок 3 важливими науковими та практичними завданнями. Сучасні умови розвитку та стрімкі інтеграційні процеси зумовлюють необхідність дослідження впливу інформаційних технологій на логістичні процеси суб'єктів господарювання. Підвищення ефективності логістичних процесів шляхом застосування інформаційних технологій покращує використання складських потужностей, автоматизований відбір вантажів та управління виробничими запасами. Інформаційні технології сприяють ефективному плануванню ресурсів розподілу та логістичних процесів. 
Економічні науки: збірник наукових праць Луцького національного технічного університету. Серія "Регіональна економіка". Випуск 18 (71). Редкол.: відп. ред. д.е.н., професор Л.Л. Ковальська. Луиьк: ІВВ Луиького НТУ, 2021. 278 с.

Аналіз останніх досліджень, у яких започатковано вирішення проблеми. Теоретичні та прикладні аспекти дослідження логістичних процесів знайшли своє відображення в роботах провідних вітчизняних та зарубіжних вчених, серед яких: М. Бернон, Н. Гринчак, А. Іваніщева, Д.Дж. Клос, Я. Корнага, М. Крістофер, К. Мельник, Дж. Сток, Ю. Тільняк, Д. Уотерс, О. Позняк, Д. Пруненко та інші. Однак, багато проблем пов'язаних із розробкою напрямів підвищення ефективності логістичних процесів шляхом використання інформаційних технологій $є$ фрагментарними, що зумовлює необхідність подальших поглиблених досліджень.

Метою статті $\epsilon$ дослідження напрямів підвищення ефективності логістичних процесів шляхом використання інформаційних технологій.

Виклад основного матеріалу дослідження 3 повним обгрунтуванням отриманих наукових результатів. Для оцінки загального стану логістики в Україні проаналізуємо міжнародний Індекс ефективності логістики (Logistics Performance Index), який розраховується міжнародним банком. Індекс враховує експертну оцінку функціонування митниці, логістичну інфраструктуру, міжнародні поставки, відстеження поставок, своєчасність поставок та логістичні компетенції (таблиця 1).

Згідно проведених досліджень, за індексом ефективності логістики Україна посіла 66 місце серед 160 країн. Індекс логістики коливається, що обумовлено двома факторами: неефективною роботою митних органів (95 позиція в світі) та погіршенням інфраструктури (105 позиція в світі). Показники своєчасності (54 позиція в світі) та відстеження (54 позиція в світі) мають значення вище середніх, що позитивно впливає на індекс ефективності логістики. Показники міжнародних відвантажень (81 позиція в світі)та логістичних компетенцій (70 позиція в світі) перебувають на середньому рівні [2].

Для удосконалення ефективності логістичних процесів пропонуємо використання інформаційних технологій: Big Data, 
Економічні науки: збірник наукових прачь Луцького національного технічного університету. Серія "Регіональна економіка". Випуск 18 (71). Редкол.: відп. ред. д.е.н., професор Л.Л. Ковальська. Луиьк: ІВВ Луцьккого НТУ, 2021. 278 с.

аналітичні платформи ланцюгів постачань, інтернет речей, штучний інтелект та машинне навчання, блокчейн.

Таблиця 1

Рейтинг країн світу за субіндексами LPI у 2018 р. [1]

\begin{tabular}{|c|c|c|c|c|c|c|c|c|c|c|c|c|c|c|}
\hline \multirow{2}{*}{ 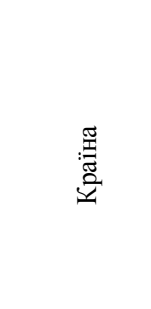 } & \multirow{2}{*}{ 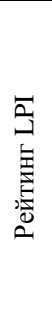 } & \multirow{2}{*}{ 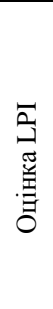 } & \multicolumn{2}{|c|}{ Митниця } & \multicolumn{2}{|c|}{$\begin{array}{c}\text { Інфра- } \\
\text { структура }\end{array}$} & \multicolumn{2}{|c|}{$\begin{array}{c}\text { Міжна- } \\
\text { родні } \\
\text { відванта- } \\
\text { ження }\end{array}$} & \multicolumn{2}{|c|}{$\begin{array}{c}\text { Логісти- } \\
\text { чна } \\
\text { компе- } \\
\text { тент- } \\
\text { ність }\end{array}$} & \multicolumn{2}{|c|}{$\begin{array}{c}\text { Відсте- } \\
\text { ження }\end{array}$} & \multicolumn{2}{|c|}{$\begin{array}{c}\text { Своє- } \\
\text { час- } \\
\text { ність }\end{array}$} \\
\hline & & & 志 & 苞 & 吾 & 营 & 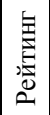 & 芶 & 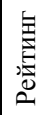 & 㸓 & 焉 & 苞 & 是 & 挡 \\
\hline Польща & 31 & 3,5 & 31 & 3,26 & 40 & 3,17 & 19 & 3,57 & 29 & 3,49 & 33 & 3,49 & 26 & 3,94 \\
\hline Угорщина & 32 & 3,41 & 36 & 3,18 & 32 & 3,31 & 35 & 3,29 & 36 & 3,27 & 29 & 3,61 & 32 & 3,82 \\
\hline Словаччина & 47 & 3,14 & 46 & 2,94 & 44 & 3,09 & 42 & 3,19 & 43 & 3,13 & 57 & 3,02 & 54 & 3,45 \\
\hline Румунія & 50 & 3,1 & 58 & 2,73 & 58 & 2,86 & 46 & 3,15 & 53 & 3,01 & 48 & 3,19 & 45 & 3,61 \\
\hline Україна & 69 & 2,83 & 95 & 2,46 & 105 & 2,38 & 81 & 2,77 & 70 & 2,76 & 54 & 3,08 & 54 & 3,45 \\
\hline Росія & 85 & 2,69 & 131 & 2,25 & 73 & 2,64 & 105 & 2,59 & 73 & 2,74 & 88 & 2,67 & 74 & 3,23 \\
\hline Білорусь & 110 & 2,54 & 126 & 2,29 & 103 & 2,39 & 124 & 2,47 & 102 & 2,53 & 124 & 2,44 & 87 & 3,1 \\
\hline Молдова & 113 & 2,52 & 122 & 2,31 & 131 & 2,21 & 90 & 2,69 & 123 & 2,36 & 133 & 2,36 & 90 & 3,1 \\
\hline
\end{tabular}

Big Data формують можливості для організацій отримувати нову цінність та створювати конкурентні переваги, а саме наявність великої кількості структурованої інформації. Для бізнесу Big Data допомагає підвищити ефективність, якість продуктів та послуг, рівень задоволеності споживачів та прибутку. Для логістики дає можливість пошуку оптимальних ланцюгів поставок та оптимізацію витрат.

Big Data дозволяє проводити різноманітні види аналізу, зокрема: описовий, який виявляе майбутні ймовірності та тенденції, дає уявлення про те, що може відбутися в майбутньому; діагностичний, за допомогою якого досліджують причинно-наслідкові зв'язки; прогностичний, у якому використовується багато методів, таких як пошук даних та штучний інтелект, для аналізу поточних даних та складання 
Економічні науки: збірник наукових праць Луцького національного технічного університету. Серія "Регіональна економіка". Випуск 18 (71). Редкол.: відп. ред. д.е.н., професор Л.Л. Ковальська. Луиьк: ІВВ Луиького НТУ, 2021. 278 с.

майбутніх сценаріїв; прескриптивний, використовує результати попередніх видів аналізу для пошуку необхідних рішень [3].

Компанія Transmetrics успішно застосовує методи Big Data, $\epsilon$ провідним постачальником програмного забезпечення для прогнозних рішень 3 оптимізації логістичної галузі. Transmetrics пропонує інтелектуальну оптимізацію програмного забезпечення послуги на базі штучного інтелекту. Продукція Transmetrics допомагає компаніям постійно підвищувати свою операційну ефективність та зменшувати витрати. Transmetrics розробляе нові інструменти для підтримки динамічного управління запасами та оцінки портфеля клієнтів. Цьому сприятимуть власні прогностичні алгоритми компанії та унікальна методологія очищення даних, яка різко скорочує час інтеграції системи.

Наступним інформаційно-технологічним методом ведення логістичних процесів $є$ застосування логістичних аналітичних платформ. Такі компанії допомагають аналізувати інформацію стосовно ланцюгів поставок, здійснювати автоматизацію процесів, зберігати та здійснювати обмін інформацією між різними системами. Аналітичні платформи досить популярні за кордоном, проте в Україні не мають широкого застосування. До сучасних логістичних платформ можна віднести: Transmetrics, Youredi, Mulesoft Anypoint, Dell Boomi, Jitterbit та інші.

Youredi iPaaS - це хмарна інтеграційна платформа, призначена для надійного обміну інформацією між різними бізнес-системами. Системи можуть розташовуватися локально, у хмарі, в різних організаціях, забезпечувати інтерфейси та використовувати типи даних. Youredi забезпечує миттєву синхронізацію інформації по всьому світу, працює як керована послуга, тому клієнтам компанії не потрібно враховувати деталі хостингу [4]. Youredi iPaaS особливо ефективно поєднує ланцюжки поставок та логістичні потоки даних між різними організаціями та континентами. Його функціональні можливості включають автоматичний аналіз та перетворення стандартних повідомлень логістичної галузі. 
Економічні науки: збірник наукових праць Луцького національного технічного університету. Серія "Регіональна економіка". Випуск 18 (71). Редкол.: відп. ред. д.е.н., професор Л.Л. Ковальська. Луиьк: ІВВ Луиького НТУ, 2021. 278 с.

Інтернет речей (IP) відноситься до екосистеми, в якій додатки та послуги керуються даними, зібраними 3 пристроїв, що взаємодіють $з$ фізичним світом. Важливі сфери застосування IP охоплюють основні сектори економіки: охорону здоров'я, освіту, сільське господарство, транспорт, виробництво, електричні мережі та багато інших [5]. Програмне забезпечення IP вирішує свої ключові сфери мереж та дій за допомогою платформ, вбудованих систем, партнерських систем та проміжного програмного забезпечення. Ці індивідуальні та головні програми відповідають за збір даних, інтеграцію пристроїв, аналітику в режимі реального часу, а також розширення програм та процесів у мережі IP. Вони використовують інтеграцію 3 критичними бізнес-системами (наприклад, системами замовлення, робототехнікою, плануванням тощо) при виконанні відповідних завдань тощо.

Оптимізація використання активів для підвищення оперативної ефективності лежить в основі цінності IP за розрахунками Cisco (один із найбільших у світі виробників мережевого обладнання), на нього припадає приблизно 25 відсотків загальної вартості ставок від IP. Зокрема, в автомобільній сфері були вкладені значні кошти у підключення технологій у транспортні засоби, включаючи системи відновлення. Прикладом таких $\epsilon$ LoJack (система для відслідковування викрадених автомобілів), послуги для водіїв у транспорті OnStar від General Motors, яка передбачає інформаційну підтримку клієнтів, забезпечує зв'язок із екстреними службами, безпеку в дорозі тощо.

Розвиток штучного інтелекту (ШІ) 3 кожним роком стає все більш популярнішим і не винятком є логістика. Зокрема у дослідженні, проведеному Crisp Research AG серед осіб, що приймають рішення в галузі IT, сектор логістики виявився одним із секторів, де найбільша кількість компаній вже активно використовує процеси машинного навчання. Стає очевидним те, що вектор до широкого застосування ШІ $є$ незворотнім і змушує суб'єктів господарювання підлаштовуватись під сучасні вимоги ринку. ШІ забезпечується обчислювальними приладами та 
Економічні науки: збірник наукових праць Луцького національного технічного університету. Серія "Регіональна економіка". Випуск 18 (71). Редкол.: відп. ред. д.е.н., професор Л.Л. Ковальська. Луиьк: ІВВ Луцьького НТУ, 2021. 278 с.

технологіями, які підтримують відбір та аналіз великих масивів інформації 3 логістики та ланцюга поставок. Це у свою чергу допомагає оптимізувати ланцюг поставок, що може зменшити експлуатаційні витрати та управляти запасами. Завдяки поєднанню ШІ та машинного навчання, компанії отримують нові уявлення про різні сфери, які включають управління складами, логістику та управління ланцюгами поставок. Інноваціями, які використовуються в цих частинах, є візуальна інспекція, керована ШІ, щоб сприймати шкоду та робити необхідний засіб, фотографуючи навантаження за допомогою виняткових камер.

Технологія блокчейну може допомогти полегшити гальмування у глобальній торговій логістиці, включаючи закупівлі, управління транспортом, відстеження, митну співпрацю та торгове фінансування. Основна увага блокчейну у логістиці зосереджена на судноплавних перевезеннях, тому що понад 50000 торгових суден, залучені світову галузь судноплавства, та численні митні органи, що регулюють перевезення вантажів.

Компанії в галузі логістики можуть застосовувати децентралізовані концепції відстеження товарів і транспортних контейнерів. Це обумовлено сучасними вимогами до прозорості в ланцюгу поставок, що дозволяє простежити від початку до кінця, впроваджувати необхідні технічні рішення. Вищезазначене $\epsilon$ проблемою для IT-рішень, які зосереджені на централізованих рішеннях із повним доступом. Блокчейн або похідні концепції можуть забезпечити засіб виправлення, оскільки вони вже вирішили ці проблеми, пов'язавши взаємозалежність блоку до ланцюга - блокчейну. Зміна транзакції на блокчейні вимагатиме зворотної сили.

Яскравим прикладом застосування блокчейну у логістиці $€$ американська компанія Shipchain. Спеціалістами компанії було створено логістичну платформу, що базується на технологіях блокчейн, для підтримки процесу доставки 3 місця відправки до місця призначення. Платформа дозволяє всім учасникам мережі отримувати оновлену інформацію про місцезнаходження 
Економічні науки: збірник наукових праць Луцького національного технічного університету. Серія "Регіональна економіка". Випуск 18 (71). Редкол.: відп. ред. д.е.н., професор Л.Л. Ковальська. Луиьк: ІВВ Луиького НТУ, 2021. 278 с.

контейнера, а також передбачуваний час прибуття через зашифровані державні книги.

Висновки. Стан розвитку логістики в Україні на середньому рівні. За індексом ефективності логістики Україна посідає 69 місце у світовому рейтингу. Проблеми розвитку логістичних процесів: високий рівень корупції, недосконала законодавча база, малоефективна робота митних та прикордонних органів, низька логістична інфраструктура, низькі темпи інноваційного розвитку.

Виділено інформаційних технологій у логістиці: Big Data, аналітичні платформи ланцюгів постачань, інтернет речей, штучний інтелект та машинне навчання та блокчейн. Вищезазначені технології базуються на зборі та аналізі великих масивів інформації для пошуку оптимальних ланцюгів постачання та підвищення ефективності логістичних процесів.

\section{Список бібліографічного опису}

1. Connecting to Compete 2018: The Logistics Performance Index and Its Indicators [Electronic resource] / [J.-F. Arvis, L. Ojala, C. Wiederer, B. Shepherd, A. Raj, K. Dairabayeva, T. Kiiski]. Mode of access: https:// www.researchgate.net/publication/327044979_Connecting_to_

Compete_2018_Trade_Logistics_in_the_-Global_Economy.

2. Офіційний сайт Світового банку [Електронний ресурс]. - Режим доступу: https://lpi.worldbank.org/

3. Riahi Y. Big Data and Big Data Analytics: Concepts, Types and Technologies. International Journal of Research and Engineering. Vol. 5 No. 9. PP. 524-528.

URL: https://www.researchgate.net/publication/328783489_Big_Data_and_Big_Data_Ana lytics Concepts Types and Technologies.

4. Reliable and versatile iPaaS. Youredi. URL: https://www.youredi.com/technology.

5. Internet of things. Tutorials point. URL: https://www.tutorialspoint.com/internet_of_things/internet_of_things_tutorial.pdf

\section{References}

1. Arvis, J.-F. Ojala, L. Wiederer, C. Shepherd, B. Raj, A. Dairabayeva, K. and Kiiski, T. (2018), "Connecting to Compete 2018: The Logistics Performance Index and Its Indicators". Available at: https://www.researchgate.net/ publication/327044979_Connecting_to_

Compete_2018_-

Trade_Logistics_in_the_Global_Economy.

2. Official site of World Bank Group (2020). Available at: https://lpi.worldbank.org. 
Економічні науки: збірник наукових праць Луцького національного технічного університету. Серія "Регіональна економіка". Випуск 18 (71). Редкол.: відп. ред. д.е.н., професор Л.Л. Ковальська. Луцьк: ІВВ Луцького НТУ, 2021. 278 с.

3. Riahi, Y. (2018), "Big Data and Big Data Analytics: Concepts, Types and Technologies". International Journal of Research and Engineering. Vol. 5 No. 9. PP. 524-528. Available at: https://www.researchgate.net/publication/328783489 Big Data and Big Data Ana lytics_Concepts_Types_and_Technologies.

4. Reliable and versatile iPaaS. Youredi. Available at: https://www.youredi.com/technology

5. Internet of things. Tutorials point. Available at:: https://www.tutorialspoint.com/internet_of_things/internet_of_things_tutorial.pdf

DOI: https://doi.org/10.36910/2707-6296-2021-18(71)-15

УДК 332.12:330.341.1

Рудь Н.Т., д.е.н., професор

Луцький національний технічний університет

\section{РОЗРОБКА МЕТОДИКИ ДІАГНОСТИКИ ІННОВАЦІЙНОЇ СИСТЕМИ РЕГІОНІВ УКРАЇНИ}

В статті наведено приклади деяких регіонів України, які уже впродовж десяти років створюють інноваційні системи. В основу розробленої методики діагностики покладені міжнародні, російські і українські методології, методи i методики.

Для побудови методики виділено елементи оцінки, за якими формуються аналітичні матриці. Методика діагностики науково-інноваційного ресурсу i освітнього потенціалу розглядається як один із засобів формування інноваційної системи регіону.

Використання методики діагностики стану науково-інноваційної діяльності у регіоні дозволяє більш ефективно здійснювати базові функції управління: мотивацію, контроль і організацію діяльності, а також спеціальні функції управління - виявлення потенціалу і ресурсу для інноваційного розвитку регіону.

Ключові слова: регіон, регіональна інноваційна система, діагностика, етапи, напрямки, індикатори.

Rud N.T.

\section{DEVELOPMENT OF DIAGNOSTIC METHODS OF INNOVATIVE SYSTEM OF REGIONS OF UKRAINE}

The article gives examples of some regions of Ukraine, which have been creating innovative systems for ten years, they have passed a certain way in this 